\title{
Upaya Memutus Rantai Infeksi Pada Limbah Padat Medis B3 (Bahan Berbahaya dan Beracun) di Rumah Sakit
}

\author{
Natasia Atania Sitepu \\ natasiaatania2@gmail.com
}

\section{Latar Belakang}

Pengetahuan dan kepedulian masyarakat akan kesehatan menyebabkan kebutuhan akan layanan rumah sakit yang bermutu semakin meningkat dari tahun ke tahun. Seiring dengan bertambahnya jumlah rumah sakit di Indonesia, maka jumlah produksi limbah padat medis mengalami peningkatan. Kondisi ini dapat memperbesar kemungkinan potensi limbah rumah sakit dalam mencemari lingkungan serta dapat menyebabkan kecelakaan kerja dan juga penularan penyakit apabila tidak dikelola dengan baik. Aktivitas rumah sakit akan menghasilkan sejumlah hasil samping berupa limbah, baik limbah padat, cair dan gas yang mengandung patogen, zat kimia yang pada umumnya masuk kategori limbah berbahaya dan beracun (B3). Dampak yang ditimbulkan oleh limbah tersebut dapat mencemari lingkungan dan kesehatan manusia.

Healthcare Associated Infections (HAIs) merupakan infeksi yang didapat saat pasien dirawat di rumah sakit dan setelah pasien dirawat lebih dari 48 jam menerima pelayanan kesehatan (Chalmers \& Straub, 2006; JCI, 2011; WHO, 2002). Perawat merupakan tenaga kesehatan yang berhubungan langsung dengan pasien dan dapat menjadi media transmisi infeksi baik bagi perawat maupun pasien (Bartley \& Russell, 2003; Kagan, Ovadia \& Kaneti, 2009).

Perawat mencegah terjadinya infeksi dengan cara memutuskan rantai penularan infeksi (Craven \& Hirnle, 2007). Kegiatan ini berkaitan dengan perilaku perawat. Perilaku perawat dalam melakukan kegiatan pencegahan dan pengendalian infeksi dapat ditunjukkan dengan peningkatan kinerja dan kepatuhan perawat dalam melakukan kegiatan pencegahan dan pengendalian infeksi.

Dalam operaionalnya RS menghasilkan limbah infeksius, limbah benda tajam, limbah patologi, dan limbah farmasi. Untuk limbah farmasi yang ada di RS sangat jarang dihasilkan, jika ada maka limbah farmasi akan disimpan pada bin berwarna kuning. Limbah farmasi ini sangat jarang dihasilkan karena obat-obatan yang tersedia di RS ini selalu habis. Untuk limbah sitotoksik 
tidak dihasilkan di RS karena tidak ada pelayanan medis yangmenghasilkan limbah sitotoksik. Untuk limbah radioaktif yang dihasilkan dari instalasi radiologi limbahnya akan di ambil oleh perusahaan yang telah menjadi rekanan dengan rumah sakit sehingga limbah radiologi tidak masuk ke dalam TPS B3 RS. Untuk limbah kimiawi, limbah logam berat, dan limbah kontainer bertekanan tidak dihasilkan oleh rumah sakit ini.

Untuk mencegah dampak dari pencemaran lingkungan yang ada di sekitar lingkungan rumah sakit maka penulis tertarik untuk mengangkat judul "Upaya Memutus Rantai Infeksi Pada Limbah Padat Medis B3 (Bahan Berbahaya dan Beracun) di Rumah Sakit” terkait dengan penjelasan HAIs dan penanganan limbah medis infeksius, mulai dari tahap pemilahan hingga pemusnahan/ penimbunan akhir.

\section{Metode}

Metode yang digunakan dalam penulisan ini adalah metode kualitatif yang dimana penulis mengumpulkan data sebanyak-banyaknya untuk dianalisis. Tulisan ini didasarkan dengan menganalisis berbagai jurnal atau karya tulis ilmiah yang berfokus pada "Upaya Memutus Rantai Infeksi Pada Limbah Padat Medis B3 (Bahan Berbahaya dan Beracun) di Rumah Sakit”. Adapun tinjauan literatur yang digunakan dalam penulisan ini menggunakan metode kajian bebas terhadap pokok bahasan yang dikumpulkan dari jurnal atau karya tulis ilmiah yang bersal dari E-book atau Google Scholar. Pengolahan ini dilakukan dengan metode membandingkan beberapa jurnal atau karya tulis ilmiah yang digunakan dan berhubungan dengan upaya memutus rantai infeksi pada limbah padat medis.

\section{Hasil}

Pengelolaan lingkungan Rumah Sakit memberikan manfaat langsung maupun tidak langsung terhadap peningkatan kualitas pelayanan Rumah Sakit secara menyeluruh. Pengelolaan lingkungan Rumah Sakit memiliki permasalahan yang kompleks. Salah satunya adalah permasalahan limbah Rumah Sakit yang sangat sensitif dengan peraturan Pemerintah. Rumah Sakit sebagai salah satu penghasil limbah terbesar, potensial menimbulkan pencemaran bagi 
lingkungan sekitarnya yang akan merugikan masyarakat bahkan Rumah Sakit itu sendiri (Adisasmito, 2008).

Pengelolaan limbah medis padat di rumah sakit sangat dibutuhkan, karena jika pengelolaan limbah medis padat sudah sesuai dan sudah dilakukan dengan benar maka dapat memutuskan mata rantai penyebaran penyakit menular yang umum dijumpai di rumah sakit yaitu infeksi nosokomial, selain itu pengelolaan yang tidak benar dapat menjadi sarang perkembangbiakan kuman, bakteri, vektor dan binatang pengganggu yang dapat menjadi faktor penyebaran penyakit. Limbah medis padat termasuk kedalam limbah B3, apabila limbah B3 di rumah sakit tidak dikelola dengan baik dapat menimbulkan dampak antara lain: mengakibatkan cedera, pencemaran lingkungan, serta menyebabkan penyakit nosokomial. Pengelolaan limbah B3 rumah sakit yang baik diharapkan dapat meminimalisir dampak yang ditimbulkan tersebut (Purwanti, Alvionita Ajeng, 2015). Partikel debu yang terdapat dalam limbah dapat menimbulkan pencemaran udara yang dapat menyebarkan kuman penyakit dan kontaminasi peralatan medis dan makanan. Pengelolaan limbah medis yang tidak dilakukan sesuai dengan standard dan peraturan yang berlaku akan mempengaruhi jumlah timbulan limbah yang dihasilkan dari aktivitas rumah sakit (Yahar,2011).

\section{Pembahasan}

HAIs ini dikenal sebagai Infeksi Nosokomial atau disebut juga sebagai infeksi di rumah sakit yang merupakan komplikasi paling sering terjadi di pelayanan kesehatan. Infeksi nosokomial adalah Infeksi yang didapatkan atau ditimbulkan pada waktu pasien di rumah sakit (Badi A, M., 2007). HAIs merupakan infeksi yang didapat pasien selama menjalani prosedur perawatan dan tindakan medis di pelayanan kesehatan setelah $\geq 48$ jam dan $\leq 30$ hari setelah keluar dari fasilitas pelayanan kesehatan (WHO, 2011). HAIs disebabkan oleh berbagai agen infeksius, termasuk bakteri, jamur, dan virus. Namun, mereka sebagian besar dapat dicegah.

Menurut Darmadi (2008), mekanisme penyebaran infeksi (mode of transmission) yaitu melalui penularan langsung dan tidak langsung. Berikut penjabarannya :

1. Penularan langsung 
Melalui droplet nuclei yang yang berasal dari petugas, keluarga atau pengunjung, melalui darah saat transfusi darah, dan penderita lainnya.

2. Penularan tidak langsung

a. Vehicle-borne, yaitu penyebaran atau penularan mikroba melalui benda-benda mati.

b. Vector borne, penyebaran atau penularan dengan perantara vektor seperti lalat.

c. Food borne, penyebaran atau penularan melalui makanan dan minuman yang disajikan.

d. Water borne, kemungkinan terjadipenyebaran atau penularan melalui air.

e. Air borne, penyebaran/penularan yang terjadi melalui udara.

Prinsip pencegahan penularan penyakit infeksi adalah melalui pemutusan rantai host/ pejamu/ inang. Perhimpunan Dokter Spesialis Penyakit Dalam Indonesia (PAPDI) merekomendasikan memutuskan rantai host/ pejamu/ inang dengan berbagai cara. Pemutusan mata rantai penyebaran virus bisa dilakukan salah satunya dengan pengelolaan limbah medis infeksius dengan benar sesuai prosedur.

Dalam tinjauan ini, limbah medis infeksius adalah yang limbah yang dihasilkan dari fasilitas pelayanan kesehatan, yang meliputi pusat kesehatan masyarakat, klinik pelayanan kesehatan atau sejenis, dan rumah sakit.

Beberapa kelompok masyarakat yang mempunyai risiko untuk mendapat gangguan karena buangan Rumah Sakit. Pertama, pasien yang datang ke Rumah Sakit untuk memperoleh pertolongan pengobatan dan perawatan Rumah Sakit. Kelompok ini merupakan kelompok yang paling rentan. Kedua, karyawan Rumah Sakit dalam melaksanakan tugas sehari- harinya selalu kontak dengan orang sakit yang merupakan sumber agen penyakit. Ketiga, pengunjung / pengantar orang sakit yang berkunjung ke Rumah Sakit, risiko terkena gangguan kesehatan akan semakin besar. Keempat, masyarakat yang bermukim di sekitar Rumah Sakit, lebihlebih lagi bila Rumah Sakit membuang hasil buangan Rumah Sakit tidak sebagaimana mestinya ke lingkungan sekitarnya. Akibatnya adalah mutu lingkungan menjadi turun kualitasnya, dengan akibat lanjutannya adalah menurunnya derajat kesehatan masyarakat di lingkungan tersebut. Oleh karena 
itu, Rumah Sakit wajib melaksanakan pengelolaan buangan Rumah Sakit yang baik dan benar dengan melaksanakan kegiatan sanitasi Rumah Sakit (WHO, 2005).

Pengetahuan dan kepedulian masyarakat akan kesehatan menyebabkan kebutuhan akan layanan rumah sakit yang bermutu semakin meningkat dari tahun ke tahun. Seiring dengan bertambahnya jumlah rumah sakit di Indonesia, maka jumlah produksi limbah padat medis mengalami peningkatan. Kondisi ini dapat memperbesar kemungkinan potensi limbah rumah sakit dalam mencemari lingkungan serta dapat menyebabkan kecelakaan kerja dan juga penularan penyakit apabila tidak dikelola dengan baik. Aktivitas rumah sakit akan menghasilkan sejumlah hasil samping berupa limbah, baik limbah padat, cair dan gas yang mengandung patogen, zat kimia yang pada umumnya masuk kategori limbah berbahaya dan beracun (B3). Dampak yang ditimbulkan oleh limbah tersebut dapat mencemari lingkungan dan kesehatan manusia.

Jumlah limbah ini berpotensi untuk mencemari lingkungan dan kemungkinan menimbulkan kecelakaan kerja serta penularan penyakit (Vinia dkk, 2017). Limbah yang dihasilkan dari upaya medis seperti puskesmas, poliklinik dan rumah sakit yaitu jenis limbah yang termasuk dalam kategori biohazard yaitu jenis limbah yang sangat membahayakan lingkungan, di mana di sana banyak terdapat buangan virus, bakteri maupun zat-zat yang membahayakan lainnya sehingga harus dimusnahkan dengan jalan dibakar dalam suhu di atas 800 0C (Jang, 2006; Gautam, 2010;).

Dengan besarnya angka limbah padat maupun cair yang dihasilkan oleh rumah sakit, dapat dibayangkan betapa besarnya kemungkinan potensi limbah rumah sakit mencemari lingkungan serta dalam menyebabkan kecelakaan kerja serta penularan penyakit jika tidak dikelola dengan baik.

Pengelolaan Limbah B3 berdasarkan Peraturan yang berlaku:

1) Pemilahan

Umumnya ditemukan bahwa pembuang limbah ke dalam keranjang tanpa dipisahkan. Perilaku Ini menimbulkan risiko kesehatan yang serius kepada para petugas penanganan limbah, untuk para pemulung di tempat pembuangan dan kepada masyarakat pada umumnya. Konsekuensi dari praktek ini yaitu mencemari air permukaan dan air tanah sumber daya di sekitar tempat pembuangan. 


\section{2) Pengemasan}

Pemilahan limbah B3 di Rumah Sakit terbuat dari bahan yang kuat, ringan, tahan karat dan kedap air serta limbah benda tajam dikumpulkan dalam satu wadah sudah sesuai dengan Keputusan Menteri Kesehatan RI No.1204/ Menkes /SK/X/2004 tentang Persyaratan Kesehatan Lingkungan Rumah Sakit Departemen Kesehatan Republik Indonesia. Di setiap ruangan yang menghasilkan limbah disediakan kemasan, menggunakan kemasan plastik sekali pakai dan warna plastik disesuaikan dengan jenis limbah baik itu limbah medis bewarna kuning dan non medis bewarna hitam, tetapi untuk limbah farmasi dan radioaktif belum diberikan kemasan sesuai dengan karakteristik hal ini belum sesuai dengan Keputusan Menteri Kesehatan RI No. 1204/MenKes/SK/X/2004 tentang Persyaratan Kesehatan Lingkungan Rumah Sakit Departemen Kesehatan Republik Indonesia. Kemasan dilengkapi penutup, simbol dan label berdasarkan karakteristik limbah sesuai dengan PP No 101 Tahun 2014 tentang Pengelolaan Limbah B3.

Wilson (1977) menyatakan bahwa penggunaan kantong plastik pelapis dalam bak sampah sangat disarankan. Kantong plastik tersebut membantu membungkus sampah saat pengangkutan sehingga mengurangi kontak langsung mikroba dengan manusia, mengurangi bau dan tidak terlihat sehingga lebih estetis dan memudahkan pencucian bak sampah.

\section{3) Pengumpulan}

Pengumpulan limbah di Rumah Sakit dilakukan setiap hari oleh petugas cleaning service menggunakan trolly pengangkut dengan APD lengkap, hal ini sesuai dengan Keputusan Menteri Kesehatan RI No. 1204/MenKes/SK/X/2004 tentang Persyaratan Kesehatan Lingkungan Rumah Sakit Departemen Kesehatan Republik Indonesia yaitu Pengumpulan limbah harus dilakukan setiap hari atau saat 2/3 volume kemasan sudah terisi.

Pada proses pengumpulan sampah rumah sakit, seharusnya sampah dikumpulkan menjadi satu dan diletakkan pada gudang sementara (titik pengumpulan) untuk diangkut oleh cleaning service yang berbeda sehingga terjadi adanya pengoperan sampah oleh cleaning service. Akan tetapi, pada keadaan di lapangan pada proses pengumpulan sampah medis maupun non medis hanya 
dilakukan oleh satu cleaning service dan langsung menuju TPS tanpa adanya titik pengumpulan dan pengoperan cleaning service. Berdasarkan Wilson (1977) perlu adanya pembuatan gudang sementara (titik penampungan sementara) yang ada di rumah sakit untuk memudahkan proses pengangkutan.

4) Penyimpanan

Lokasi penyimpanan limbah atau TPS B3 Rumah Sakit bebas banjir dan tidak rawan bencana alam dan berada dalam penguasaan penghasil limbah hal ini sesuai dengan PP Nomor 101 Tahun 2014 tentang Pengelolaan Limbah B3.

TPS B3 memiliki saluran drainase, bak penampung, penerangan, ventilasi, dapat melindungi limbah dari sinar matahari dan hujan. Lantai bangunan kedap air, rata, tidak retak, serta dilengkapi simbol dan label sesuai dengan karakteristik limbah B3 dan terdapat APAR, hal ini sesuai dengan PP Nomor 101 Tahun 2014 tentang Pengelolaan Limbah B3.

5) Pengangkutan

Pengangkutan limbah padat B3 dari Rumah Sakit ke pengolah oleh pihak ketiga menggunakan kendaraan khusus pick up yang tertutup, dilengkapi dengan simbol karakteristik B3 dan berplat bewarna kuning khusus kendaraan pengangkut limbah. Hal ini sesuai dengan PP Nomor 101 Tahun 2014 tentang Pengelolaan Limbah B3. Petugas juga menggunakan APD berupa hanscoen dan masker saat memasukkan limbah ke dalam kendaraan pengangkut. Menurut Wilburn (2004), tindakan kesehatan dan keselamatan pekerja meliputi pelatihan kerja, penyediaan alat dan pakaian, serta program kesehatan seperti imunisasi dan cek kesehatan.

Hal ini sesuai dengan Wisaksono (2001), alat angkut limbah medis harus mudah dibersihkan dan dikeringkan. Selain itu, troli tersebut dilengkapi dengan penutup, karena disarankan menggunakan wadah tertutup yang kokoh (Kepmenkes 1204 Tahun 2004).

6) Pengolahan

Setiyono (2001), menyatakan bahwa dampak yang ditimbulkan oleh limbah B3 yang dibuang langsung ke lingkungan sangat besar dan dapat bersifat akumulatif, sehingga dampak tersebut akan berantai mengikuti proses pengangkutan (sirkulasi) bahan dan jaring-jaring rantai makanan. Untuk mencapai 
sasaran dalam pengelolaan limbah perlu di buat dan diterapkan suatu sistem pengelolaan yang baik, terutama pada sektor sektor kegiatan yang sangat berpotensi menghasilkan limbah B3. Salah satu sector kegiatan yang sangat berpotensi menghasilkan limbah B3 adalah sector industri. Sampai saat ini sektor industry merupakan salah satu penyumbang bahan pencemar yang terbesar di kota-kota besar di Indonesia yang mengandalkan kegiatan perekonomiannya dari industri. Untuk menghindari terjadinya pencemaran yang ditimbulkan dari sektor industri, maka diperlukan suatu sistem yang baik untuk melakukan pengawasan dan pengelolaan limbah industri, terutama limbah B3-nya.

Pemusnahan limbah medis di rumah sakit ini dilakukan dengan menggunakan incinerator. Hasil pembakarannya kurang sempurna. Sisa jarum suntik yang dibakar tidak bisa hancur. Menurut Lemieux et al., (2004) hasil penelitian dalam beberapa tahun terakhir ini dikatakan bahwa pembakaran sampah pada kondisi pembakaran dan suhu yang rendah dapat menimbulkan gas racun dioksin dan furan. Efek samping dioksin terhadap manusia adalah perubahan kode keturunan (marker) dari tingkat pertumbuhan awal dari hormon (Sumaiku, 2007).

\section{Penutup}

Pengelolaan sampah medis dan non medis rumah sakit sangat dibutuhkan bagi kenyamanan dan kebersihan rumah sakit karena dapat memutuskan mata rantai penyebaran penyakit menular, terutama infeksi nosokomial. Jumlah limbah medis yang semakin meningkat dengan tidak diimbangi dengan fasilitas pengelolaan limbah medis yang memadai

Proses pengelolaan limbah medis padat melewati beberapa tahap yaitu pemilahan, pengemasan, pengumpulan, penyimpanan, pengangkutan, dan pengolahan yang mengacu pada peraturan 1204/MENKES/SK/X/2004 tentang Persyaratan Lingkungan Rumah Sakit. Pengelolaan

limbah medis masih banyak ditemukan bercampur dengan limbah non medis dan limbah benda tajam, pemusnahan limbah medis padat menggunakan incinerator tidak menghasilkan suhu yang sempurna sehingga limbah benda tajam tidak hancur.

Sebaiknya menyediakan kantong plastik berwarna cokelat untuk menampung limbah kimia dan farmasi. Sebaiknya membuat jalur khusus khusus untuk pengangkutan limbah B3 rumah sakit 
untuk menghindari area yang dilalui banyak orang. Sebaiknya memberikan imunisasi hepatitis kepada cleaning service yang terlibat dalam penanganan limbah B3 untuk menghindari risiko terkena infeksi apabila terjadi kecelakaan kerja. Penyediaan wastafel dan sabun cuci tangan di TPS juga diperlukan untuk mengurangi risiko pencemaran kuman penyakit.

\section{Daftar Pustaka}

Astuti, A., \& Purnama, S. (2014). Kajian Pengelolaan Limbah di Rumah Sakit Umum Provinsi Nusa Tenggara Barat (NTB). Community Health, 2(1), 12-20.

Dewi, F., Handiyani, H., \& Kuntarti, K. (2016). Memutus Rantai Infeksi melalui Fungsi Pengorganisasian Kepala Ruang Rawat. Jurnal Keperawatan Indonesia, 19(2), 107-115.

Maulana, M., Kusnanto, H., \& Suwarni, A. (2017). Pengolahan limbah padat medis dan pengolahan limbah bahan berbahaya dan beracun di RS swasta kota jogja. The 5TH URECOL Proceeding, 184-190.

Nugraha, C. (2020). Tinjauan Kebijakan Pengelolaan Limbah Medis Infeksius Penanganan Corona Virus Disease 2019 (Covid-19). JUKMAS: Jurnal Untuk Masyarakat Sehat, 4(2), 216-229.

Nurseha, D. (2013). Pengembangan tindakan pencegahan infeksi nosokomial oleh Perawat di rumah sakit berbasis health belief model. Jurnal Ners, 8(1), 64-71.

Pertiwi, V., Joko, T., \& Dangiran, H. L. (2017). Evaluasi Pengelolaan Limbah Bahan Berbahaya Dan Beracun (B3) Di Rumah Sakit Roemani Muhammadiyah Semarang. Jurnal Kesehatan Masyarakat (eJournal), 5(3), 420-430.

Ranti, A., Nurul, H., Sadono, S., \& Lubis, B. P. (2020). TINJAUAN PENANGANAN LIMBAH MEDIS PADAT DI TPS (TEMPAT PENAMPUNGAN SEMENTARA) RUMAH SAKIT UMUM DAERAH CIBABAT KOTA CIMAHI TAHUN 2020 (Doctoral dissertation, Politeknik Kesehatan Kemenkes Bandung).

ROSA, D. E. M., KEP, M., \& SARI, N. LAPORAN PENELITIAN KOLABORASI DOSEN-MAHASISWA INFECTION CONTROL RISK ASSESMENT DAN STRATEGI PENURUNAN INFEKSI DAERAH OPERASI DI RUMAH SAKIT.

Simamora, R. H. (2020). Learning of Patient Identification in Patient Safety Programs Through Clinical Preceptor Models. Medico Legal Update, 20(3), 553-556.

Simamora, R. H. (2019). Pengaruh Penyuluhan Identifikasi Pasien dengan Menggunakan Media Audiovisual terhadap Pengetahuan Pasien Rawat Inap. Jurnal Keperawatan Silampari, 3(1), 342-351. 
Yustiani, Y. M. (2019). EVALUASI OPERASIONAL SISTEM PENGELOLAAN LIMBAH PADAT MEDIS DI RUMAH SAKIT GARUT. ENVIROSAN: Jurnal Teknik Lingkungan, 2(1), 14-18. 